\title{
Partial resistance to Bean golden mosaic virus in a transgenic common bean (Phaseolus vulgaris L.) line expressing a mutated rep gene
}

\author{
Josias C. Faria $^{\mathrm{a}}$, Margareth M.C. Albino ${ }^{\mathrm{b}}$, Bárbara B.A. Dias ${ }^{\mathrm{b}}$, Letícia J. Cançado ${ }^{\mathrm{b}}$, \\ Nicolau B. da Cunha ${ }^{\mathrm{b}}$, Lílian de M. Silva ${ }^{\mathrm{b}}$, Giovanni R. Vianna ${ }^{\mathrm{b}}$, Francisco J.L. Aragão ${ }^{\mathrm{b}, *}$ \\ ${ }^{a}$ Embrapa Arroz e Feijão, Rodovia GO-462, km 12 Zona Rural C.P. 179, 75375-000 Santo Antônio de Goiás, GO, Brazil

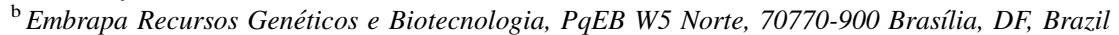 \\ Received 12 November 2005; received in revised form 2 June 2006; accepted 2 June 2006 \\ Available online 5 July 2006
}

\begin{abstract}
The rep gene of Bean golden mosaic virus (BGMV) is essential for virus replication. A mutated rep gene with amino acid codon change in the putative nucleoside triphosphate (NTP) binding motif D262R was created. Phaseolus vulgaris transformation was achieved with a vector that contained the mutated rep and bar genes. A total of 17 initial $\left(\mathrm{T}_{0}\right)$ transformants were analyzed. One line (M1/4) showed tolerance to glufosinate ammonium and partial resistance to the virus, that is, disease incidence depended on inoculation level. The incidence of BGMV increased with the increasing number of viruliferous whiteflies per plant, both in the transgenic and in the control plants. However, the number of symptomless plants was significantly higher in the transgenic group. The line M1/4 was studied during several generations and presented stability in the transgene loci and virus resistance. Southern blot analysis with genomic DNA of eight generations led to an estimate of two copies of the rep gene integrated at the same locus. RT-PCR analysis revealed the presence of both bar and rep genes transcripts. The mutated REP protein was present in amounts detectable by Western blot analysis in transgenic plants.
\end{abstract}

(C) 2006 Elsevier Ireland Ltd. All rights reserved.

Keywords: BGMV; Dry bean; Geminivirus; rep gene transdominance; Virus resistance

\section{Introduction}

Golden mosaic of common beans (Phaseolus vulgaris L.) is caused by the Bean golden mosaic virus (BGMV) that belongs to the genus Begomovirus (family Geminiviridae). Characteristic symptoms of the disease are yellow-green mosaic of leaves, and stunted or distorted growth, which may vary among genotypes. Similar diseases were described in Puerto Rico, Guatemala, the Dominican Republic, Mexico, and the United States [1]. Phylogenetic studies and differences in biological properties, such as sap transmissibility, supported the taxonomic separation between bean-infecting geminiviruses isolates from Brazil (designed BGMV) and isolates from Central America, the Caribbean Basin and Mexico (designed Bean golden yellow mosaic virus, BGYMV). In addition, pseudorecombinants between components of BGMV and BGYMV also

\footnotetext{
* Corresponding author. Tel.: +55 61 34484777; fax: +55 6134484777 . E-mail address: aragao@cenargen.embrapa.br (F.J.L. Aragão).
}

supported the separation of these two viruses into distinct populations [2,3].

BGMV is a typical circular single-stranded DNA plant virus with bipartite genome, containing 2617 nucleotides in the component A and 2580 nucleotides in the component B [2]. Each DNA component is separately encapsidated in twinned particles. Both components are necessary for plant infection, even though the A component, by itself, can infect isolated tobacco plant protoplasts [4]. Except for a region of approximately 200 nucleotides, known as the common region, there is no significant homology between the two components. Geminivirus replication is achieved via a replicative form abundantly found in tissue of plants actively growing.

Transgenic plants have been obtained with the replication associated protein (REP; rep gene), which has been the choice gene for pathogen-derived resistance in begomoviruses, either in its entireness or in a partial or truncated form [5-10]. After plant inoculation the results varied from reduced symptom expression and viral DNA replication to complete resistance [11]. The REP protein is involved in functions such as directing the replication complex to the origin of replication 
[11]. REP/RepAC1 is an oligomeric protein that binds to double-stranded DNA, catalyzes cleavage and ligation of single-stranded DNA, and initiates and terminates plus strand replication. It also interacts with several host proteins, including the cell cycle regulator, retinoblastoma, and essential components of the cell DNA replication machinery, like proliferating nuclear cells [12]. The REP protein expression back-regulates its own synthesis at the level of transcription. A motif identified as the NTP binding site, with the consensus sequence $\mathrm{EGX}_{4} \mathrm{GKTX}_{32} \mathrm{DD}$, was described by Hanson et al. [13]. A mutation of the aspartic acid (at position 262) within this motif completely abolished the infectivity of BGYMV. When a construct of the rep gene with this mutation was co-inoculated with the component $\mathrm{A}$, in tobacco protoplasts, there was up to $100 \%$ inhibition of replication of the viral DNA of BGYMV through a transdominant inhibition mechanism [4].

The objective of the present work was to transform common beans with a construct of the rep gene from BGMV mutated at the amino acid 262, through the replacement of an aspartic acid by an arginine (D262R) to evaluate its resistance to BGMV. Here, we report the production of a transgenic common bean line expressing the rep gene and presenting resistance to the virus.

\section{Material and methods}

\subsection{Vector construct}

Infectious clones of BGMV from Brazil, pBZA1, and pBZB1, were used for vector construct $[2,14]$. Their sequences have been deposited in the GenBank under the accession numbers M88686 and M88687, respectively. The cassette containing the double $35 \mathrm{~S}$ promoter from Cauliflower mosaic virus (CaMV), enhancer sequence from Alfalfa mosaic virus, gus::nptII fusion, and nos terminator from the plasmid pBI426 [15] was excised with HindIII and EcoRI blunt ended and ligated into the filled-in $\mathrm{XbaI}$ restriction site of a pBS II KS+ (Stratagene Inc., La Jolla, CA, USA). This resulted in the vector pBS-ex426. The DNA A was excised from pBZA1 by digestion with HindIII and circularized. This molecule was used to amplify the block of rep-trap-ren genes by PCR (see the Section 2.4). The primer PBZAC7NcoI (5'-TACAAGCCATGGCACCACCAAAGCG-3') was used to include a $N c o$ I restriction site (underlined) into the start codon of the rep gene and the primer PBZAR1076XhoI ( $5^{\prime}$-TGCTACTCGAGAAATTCGGATCT- $\left.{ }^{\prime}\right)$ was used to include a $X h o I$ restriction site (underlined) downstream the stop codon of the ren gene. The PCR amplified fragment was cloned in the NcoI and XhoI sites of the vector pBS-ex426, replacing the gus::nptII gene fusion, resulting in the pT-WT construct. Site-directed mutagenesis was performed essentially as described by Kunkel et al. [16] to create the mutation in amino acid 262 replacing an aspartic acid by an arginine, and to introduce the unique restriction site $\mathrm{NruI}$ using the primer PBZAv1876NruI (5'-CGGTGCGATGTCGCGAATGACGTTATACTCAGC- $3^{\prime}$ ). The complete clone construct (pT-M) was sequenced to confirm the presence of the desired mutation and determine that no secondary mutation had been introduced. For common bean transformation, a cassette with the bar gene (that confers tolerance to the herbicide glufosinate ammonium), under control of the $35 \mathrm{~S}$ CaMV promoter, was removed with EcoRI from the vector $\mathrm{pB} 5 / 35 \mathrm{Sbar}$ [17] and cloned in the same restriction site of pT-M resulting in the vector pT-M1 (Fig. 1).

\subsection{Common bean transformation}

Transgenic common bean plants (cultivar Olathe Pinto) were produced as described by Aragão et al. [18]. Briefly, mature seeds were surface sterilized and soaked in distilled water for 16-18 $\mathrm{h}$. Then, the embryonic axes were excised from the seeds and the apical meristems were exposed by removing their primary leaves. The embryonic axes were placed with the apical region directed upward in Petri dishes containing basal MS medium immediately before the bombardment. The bombardment was conducted using a high-pressure heliumdriven particle acceleration device built in our laboratory. The embryonic axes, bombarded with the vector pT-M1, were cultivated on MS medium containing $44.3 \mu \mathrm{M}$ BAP to induce multiple shoot development. After 3 weeks in culture, the bombarded apical meristems produced elongated shoots, which were treated with $0.03 \%$ aqueous solution of Lyberty ${ }^{\mathrm{TM}}$ (200 $\mathrm{g}^{-1}$ glufosinate ammonium), when they had reached 2$4 \mathrm{~cm}$ in length. The herbicide tolerant shoots $\left(\mathrm{T}_{0}\right.$ generation) were rooted and transferred to a plastic pot containing autoclaved soil:vermiculite (1:1) and covered with a plastic bag for a week to acclimatize. To detect the presence of the rep gene, plants were analyzed by PCR.

\subsection{Transgenic plant evaluation: inoculation with $B G M V$ and symptoms evaluation}

Transgenic plants $\left(\mathrm{T}_{0}\right.$ generation) were inoculated with BGMV by exposing them to 20-30 viruliferous whiteflies for 3 days. A viruliferous whitefly colony was maintained on $P$. lunatus L. and Glycine max Merrill, with the periodic replacement of older plants by young ones. After the inoculation access period the insects were removed and the plants transferred to an insect free greenhouse for symptom development and evaluation. Evaluations were done by recording the first date of vein clearing, and then daily until full disease symptoms had developed on control plants.

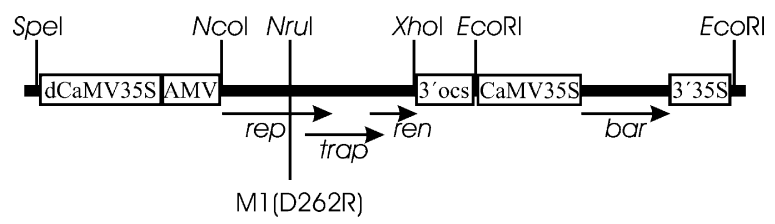

Fig. 1. Schematic representation (not to scale) of pT-M1 vector used to transform common bean. In the rep, trap, and ren wild-type viral genes sequence, the rep gene was mutated [mutation M1 (D262R)] creating a NruI site. 


\subsection{PCR analysis}

DNA was isolated from leaf disks according to Edwards et al. [19]. Each PCR reaction was carried out in $25 \mu \mathrm{l}$ of reaction mixture containing $10 \mathrm{mM}$ Tris- $\mathrm{HCl}(\mathrm{pH} 8.4), 50 \mathrm{mM}$ $\mathrm{KCl}, 2 \mathrm{mM} \mathrm{MgCl}_{2}, 160 \mu \mathrm{M}$ of each dNTP, $200 \mathrm{nM}$ of each primer, $2 \mathrm{U}$ of Taq polymerase (Invitrogen, Carlsbad, CA, USA) and 10-20 ng of genomic DNA. The mixture was overlaid with mineral oil, denatured for $5 \mathrm{~min}$ at $95{ }^{\circ} \mathrm{C}$ and amplified for 35 cycles $\left(95^{\circ} \mathrm{C}\right.$ for $1 \mathrm{~min}, 55^{\circ} \mathrm{C}$ for $1 \mathrm{~min}, 72^{\circ} \mathrm{C}$ for $1 \mathrm{~min}$ ) with a final extension of $7 \mathrm{~min}$ at $72{ }^{\circ} \mathrm{C}$. The PCR reactions were carried out in a thermocycler (PTC-100, MJ Researcher, USA). The reaction mixture was then loaded directly onto a $1 \%$ agarose gel, stained with ethidium bromide and visualized with UV light. The primer pair BzA237 $\left(5^{\prime}-\right.$ AGGTGGTATACTCTGGTCGTT- $\left.3^{\prime}\right)$ and BzA1137 (5'GGAGGTCAACAGACAGCTAAT- $3^{\prime}$ ) was used to amplify a 901-bp sequence to screen the transgenic plants for the presence of the rep-trap-ren cassette. The primer pair T3 $\left(5^{\prime}\right.$ CGCAATTAACCCTCACTAAAGGG- $\left.3^{\prime}\right)$ and AC1vATG (5'ACGCTTTGGTGGTGCCATGG- $3^{\prime}$ ) was used to amplify the complete promoter region confirming its presence. Primers BAR90 (5'-GGTCTGCACCATCGTCAACC-3') and bar536C $\left(5^{\prime}\right.$-CTGAAGTCCAGCTGCCAGAA- $\left.3^{\prime}\right)$ were utilized to amplify a 446 bp sequence from the bar gene.

\subsection{Southern blot analysis}

Genomic DNA was isolated using the DNeasy Plant Mini Kit (Qiagen, Valencia, CA, USA). Southern blotting was carried out as described [20]. Genomic DNA $(15 \mu \mathrm{g})$ was digested with XhoI, separated on an $1 \%$ agarose gel and transferred to a nylon membrane (Hybond N+, Amershan Pharmacia Biotech, Buckinghamshire, UK). Hybridization was carried out using the 901-bp PCR-generated sequence as probe for the rep gene (Fig. 1). The probe was labeled with $\alpha^{32} \mathrm{P}$ dCTP $\left(3000 \mathrm{Ci} \mathrm{mol}^{-1}\right)$ using a random primer DNA labeling kit (Pharmacia Biotech) according to the manufacturer's instructions. Membrane was pre-hybridized for $2 \mathrm{~h}$ at $65^{\circ} \mathrm{C}$. After prehybridization, the denatured probe was added at $2 \mathrm{ng} / \mathrm{ml}$ and membrane incubated for $16 \mathrm{~h}$ at $65^{\circ} \mathrm{C}$. After hybridization, the membrane was washed twice with $2 \times$ SSPE, $0.1 \%$ (w/v) SDS at room temperature for $10 \mathrm{~min}$, washed once with $1 \times \mathrm{SSPE}$, $0.1 \%(\mathrm{w} / \mathrm{v}) \mathrm{SDS}$ at $65^{\circ} \mathrm{C}$ for $15 \mathrm{~min}$ and once with $0.1 \times \mathrm{SSPE}$, $0.1 \%(\mathrm{w} / \mathrm{v}) \mathrm{SDS}$ at $65^{\circ} \mathrm{C}$ for $10 \mathrm{~min}$.

\subsection{RT-PCR expression analysis}

Total RNA was extracted using the RNAeasy kit (Qiagen, Valencia, CA, USA) from $200 \mathrm{mg}$ of fresh leaves. Possible remaining genomic DNA was eliminated by DNase digestion of the RNA samples. A PCR reaction was carried out using RNA to confirm DNA removal. Two micrograms of total RNA were used to produce cDNA using the reverse transcriptase Superscript II (Invitrogen, Carlsbad, CA, USA), according to the protocol suggested by the manufacturer. PCR reactions were carried out as described above except that $25 \mathrm{ng}$ of cDNA [quantified using the DyNA Quant 200 fluorimeter (Amershan Pharmacia Biotech, Buckinghamshire, UK)] was used as a template with 24 cycles of amplification. The primers BzA237 and BzA1137 were used to amplify a 901-bp sequence from the rep-trap-ren cassette. The primers BAR90 and BAR536C were used to amplify a 446-bp sequence from the bar gene. As an internal control, the primers rRNA1 (5'-AACGGCTACCACATCCAAGG- $\left.3^{\prime}\right)$ and rRNA2C (5'-TCATTACTCCGATCCCGAAG- $3^{\prime}$ ) were used to amplify a 459 bp sequence from the $P$. vulvaris $18 S$ rRNA gene (Pv18SrRNA) (Report TC238, The TIGR $P$. vulgaris Gene Index; www.tigr.org).

\subsection{Western blot analysis}

Proteins were extracted from leaves, seeds, stem, and flowers according to Aragão et al. [21]. Western blot analyses were carried out as described [21]. Fifty micrograms of total protein of each sample were fractionated using SDS-PAGE on a $12 \%$ acrylamide gel and electroblotted onto a nitrocellulose membrane. The REP protein was identified using the anti-REPBGYMV polyclonal antiserum raised in mouse (1:3000), rabbit anti-mouse IgG conjugated (1:5000) to alkaline phosphatase and visualized using BCIP (5-bromo-4-chloro-3-indolyl phosphate) and nitroblue tetrazolium.

\subsection{Disease resistance testing}

Transgenic plants of advanced generations were analyzed for their resistance to BGMV by exposing to populations of 20110 viruliferous whiteflies per plant for a 3-day inoculation access period, using 8-day old seedlings. Seeds were germinated in 300-ml containers filled with a fertilized soil mixture to facilitate handling. Whiteflies were placed on individual common bean seedlings contained in a cage covered with a nylon tissue to prevent the insects from escaping. After inoculation the seedlings were transferred to a $3-\mathrm{kg}$ pot filled with fertilized soil mix. Twenty-five plants of each transgenic or non-transgenic Olathe Pinto beans were used for each whitefly population evaluated. The final number of whiteflies per plant was counted at the end of the inoculation access period. Disease evaluation was done on a visual basis by recording the first date of vein clearing, and then daily until the end of the experiment. The complete experiment was repeated three times.

\section{Results}

Out of 5669 bombarded embryonic axes, 17 common bean transformants $\left(\mathrm{T}_{0}\right.$ generation) were obtained (approximately $0.3 \%$ ) based on the tolerance to glufosinate ammonium and PCR detection of the bar and rep genes. All generated plants had normal phenotype (plant height, site of insertion of first pod, number of branches, internode length, foliar area, total number of flowers, pods, and seeds) and were cultivated to set seeds in the greenhouse.

Transgenic plants were tested for their resistance to the BGMV. One line (M1/4) showed resistance to the BGMV and 


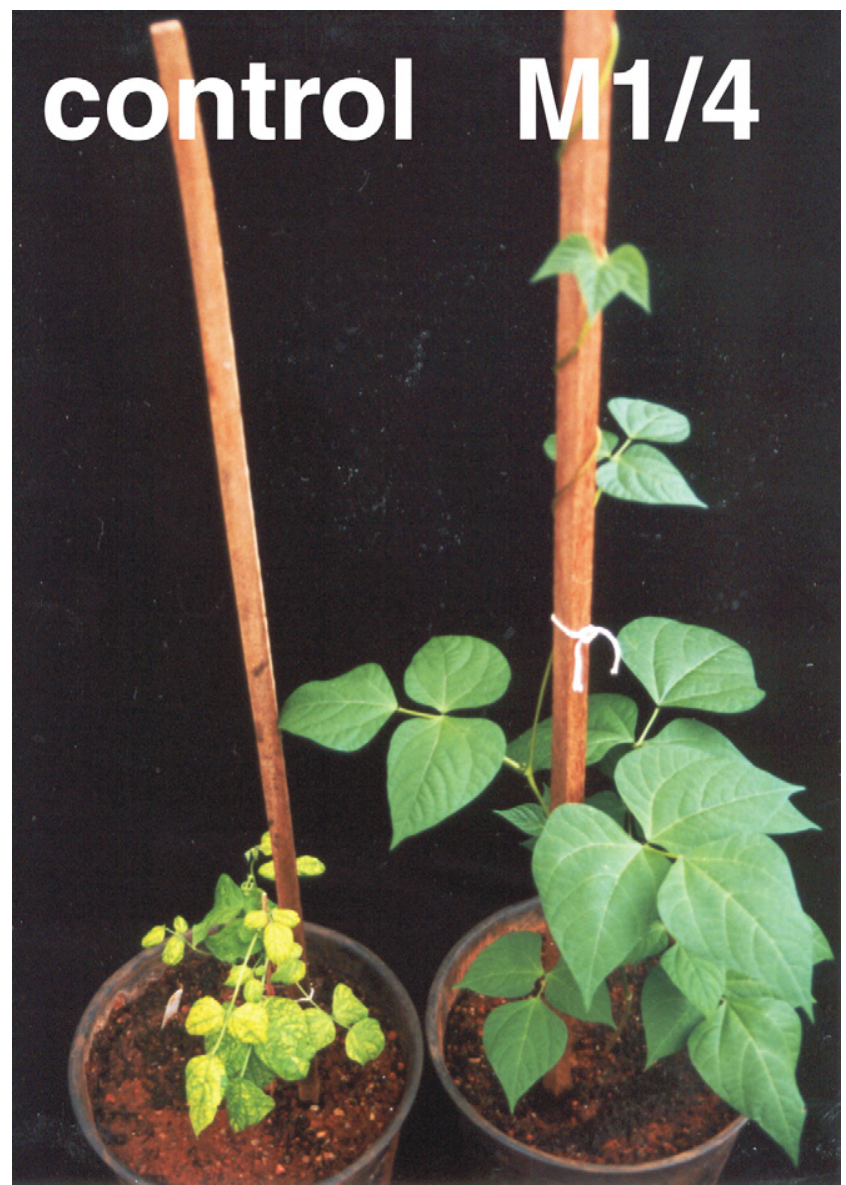

Fig. 2. BGMV symptoms in a non-transgenic plant (control) showing delayed maturity, yellowing of leaves, and severe pod malformation, and a transgenic plant (M1/4) ( $\mathrm{T}_{5}$ generation) showing resistance to the virus. (For interpretation of the references to colour in this figure legend, the reader is referred to the web version of the article.)

transferred both rep and bar genes to its progeny $\left(\mathrm{T}_{1}\right.$ generation) (Fig. 2). The line M1/4 set six seeds $\left(\mathrm{T}_{1}\right.$ generation). All M1/4 $T_{1}$ seeds were germinated and the plants were resistant to glufosinate ammonium. However, only four plants were resistant to BGMV. The two susceptible plants yielded no seeds. The $T_{2}$ progeny derived from seed of the four

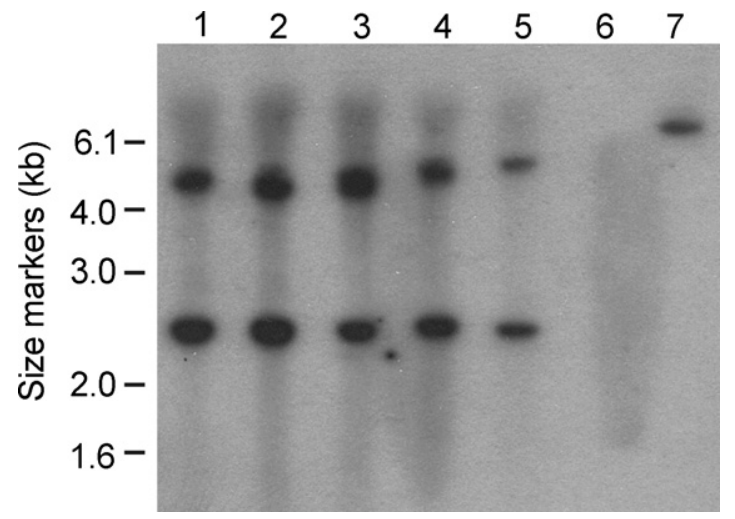

Fig. 3. Southern blot analysis of the transgenic common bean line M1/4 to detect the cassette rep-trap-ren. Genomic DNA was digested with XhoI and probed with a 901-bp PCR-generated fragment for the rep gene. Lane 1: $\mathrm{T}_{0}$ transgenic plant (primary transformant). Lane 2: $\mathrm{T}_{2}$ transgenic plant (second generation). Lane 3: $\mathrm{T}_{4}$ transgenic plant (fourth generation). Lane 4: $\mathrm{T}_{6}$ transgenic plant (sixth generation). Lane 5: $\mathrm{T}_{8}$ transgenic plant (eighth generation). Lane 6: non-transgenic plant. Lane 7: plasmid vector (pT-M1).

BGMV resistant plants (numbered 1, 3, 4, and 6) was analyzed (Table 1). $T_{2}$ plants from $T_{1-1}\left(T_{2}\right.$ generation derived from the plant number 1$)$ and $T_{1-4}\left(T_{2}\right.$ generation derived from the plant number 4) showed the highest number of BGMV resistant plants (31 out of 35 and 11 out of 12, respectively). Only $T_{2}$ plants from $\mathrm{T}_{1-4}$ showed glufosinate ammonium susceptible progenies (5 out of 12). Seeds from $T_{2}$ plants $\left(T_{3}\right.$ generation) derived from $\mathrm{T}_{1-1}$, which were PCR positive for both rep and promoter region and resistant to BGMV infection, were pooled. Except for one plant, all $\mathrm{T}_{3}$ carried the rep and bar genes (127 plants tested). All PCR-positive plants were tolerant to glufosinate ammonium and showed BGMV resistance.

Southern blot analysis of genomic DNA isolated from the $\mathrm{T}_{0}, \mathrm{~T}_{2}, \mathrm{~T}_{4}, \mathrm{~T}_{6}$, and $\mathrm{T}_{8}$ generations of transgenic common bean line M1/4, was carried out to evaluate the integration of the introduced rep-trap-ren cassette. The results revealed the presence of the rep sequence in all generations. As the vector pT-M1 has a unique XhoI restriction site (Fig. 1), Southern blot analysis confirmed the integration of two transgene copies in the line M1/4 (Fig. 3). Southern analysis with plants of the $T_{0}$, $\mathrm{T}_{2}, \mathrm{~T}_{4}, \mathrm{~T}_{6}$, and $\mathrm{T}_{8}$ generations showed the same pattern of DNA

Table 1

Analysis of the progenies $\left(T_{1}, T_{2}\right.$, and $\left.T_{3}\right)$ from the $T_{0}$ transgenic plant $M 1 / 4$

\begin{tabular}{|c|c|c|c|c|c|c|}
\hline \multirow[t]{2}{*}{ Plant identification } & \multicolumn{2}{|c|}{ PCR for rep gene ${ }^{a}$} & \multicolumn{2}{|c|}{$\begin{array}{l}\text { Reaction to glufosinate } \\
\text { ammonium }^{\text {b }}\end{array}$} & \multicolumn{2}{|c|}{$\begin{array}{l}\text { Reaction to Bean golden } \\
\text { mosaic virus }\end{array}$} \\
\hline & Positive & Negative & $\mathrm{T}$ & $\mathrm{S}$ & $\mathrm{T}$ & $\mathrm{S}$ \\
\hline $\mathrm{T}_{1}$ plants & 6 & 0 & 6 & 0 & 4 & 2 \\
\hline $\mathrm{T}_{2}$ plants $\left(\mathrm{T}_{1-1}\right)^{\mathrm{c}}$ & 23 & 12 & 35 & 0 & 31 & 4 \\
\hline $\mathrm{T}_{2}$ plants $\left(\mathrm{T}_{1-3}\right)^{\mathrm{c}}$ & 7 & 32 & 39 & 0 & 7 & 32 \\
\hline $\mathrm{T}_{2}$ plants $\left(\mathrm{T}_{1-4}\right)^{\mathrm{c}}$ & 6 & 6 & 7 & 5 & 11 & 1 \\
\hline $\mathrm{T}_{2}$ plants $\left(\mathrm{T}_{1-6}\right)^{\mathrm{c}}$ & 5 & 34 & 39 & 0 & 20 & 19 \\
\hline $\mathrm{T}_{3}$ plants $^{\mathrm{d}}$ & 42 & 0 & 42 & 0 & 41 & 1 \\
\hline
\end{tabular}

\footnotetext{
${ }^{a}$ Each column shows the number of plants expressing the trait analyzed.

b T: tolerant; $\mathrm{S}$ : susceptible.

${ }^{c} \mathrm{~T}_{2}$ plants numbered as $\mathrm{T}_{1-1}, \mathrm{~T}_{1-3}, \mathrm{~T}_{1-4}$, and $\mathrm{T}_{1-6}$ were the progenies of the four BGMV resistant plants in the $\mathrm{T}_{1}$ generation

${ }^{d} \mathrm{~T}_{3}$ plants were derived from the $\mathrm{T}_{2}$ plants of group $\mathrm{T}_{1-1}$.
} 


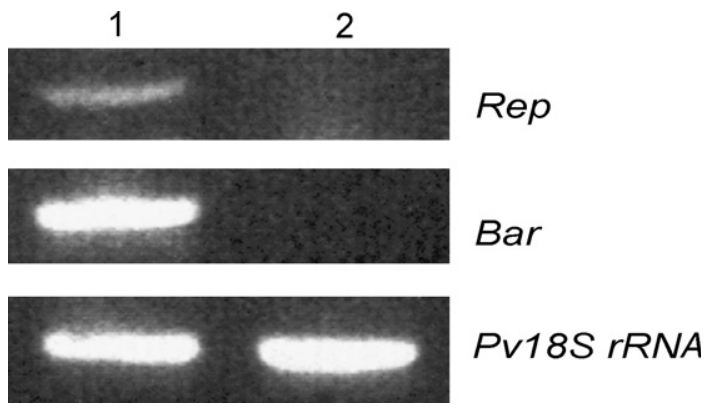

Fig. 4. RT-PCR analysis for the presence of rep and bar genes transcripts in leaves of the transgenic and non-transgenic common bean plants. Transcripts from the $P$. vulgaris $18 S r R N A$ gene were analyzed as an internal control. Lane 1: transgenic plant (line M1/4; $\mathrm{T}_{6}$ generation) and Lane 2: non-transgenic plant (control).

bands. DNA isolated from a non-transgenic plant did not hybridize with the rep probe (Fig. 3).

Transgenic and non-transgenic plants were analyzed by RTPCR to detect rep and bar gene transcripts. Transgenic plants showed both bar and rep gene expression in the leaves (Fig. 4). The amplified fragment for the rep gene was fainter compared to the fragment amplified from bar gene. Non-transgenic plants lacked genes expression. Both transgenic and non-transgenic leaves showed similar levels of the Pv18SrRNA endogenous gene (Fig. 4).

Western blot analysis revealed that the REP protein was expressed in some tissues of the M1/4 transgenic common bean line, as judged from the presence of the expected $42-\mathrm{kDa}$ protein (Fig. 5). The presence of the REP protein was detected in leaves and stems. A weak signal was observed in floral tissues. However, no signal was observed in seed tissues. In addition, a stronger signal was observed in non-transgenic plants infected with the BGMV and no signals were observed in the control tissues (from non-transgenic healthy plants).

The incidence of BGMV increased with the extent of viruliferous whiteflies per plant, both in the transgenic as well as in the control plants. It should be noted, however, that there is a higher number of symptomless plants in the transgenic group (Fig. 6). Attempts to amplify virus genes by PCR from symptomless plants failed (data not shown). Disease symptoms on transgenic plants developed within the same time frame as on the control plants. Inoculation of transgenic plants with up to 13 viruliferous whiteflies did not result in viral infection while $29.4 \%$ of non-transgenic plants showed viral symptoms (Fig. 6).

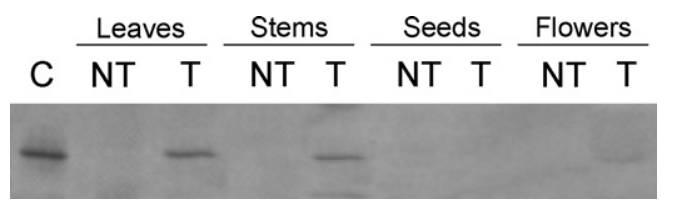

Fig. 5. Western blot analysis for the presence of REP protein in the leaves, stems, seeds, and flowers of non-inoculated transgenic $(\mathrm{T})$ and non-transgenic (NT) plants. C represents leaves from a non-transgenic plant 8 days after inoculation with BGMV.

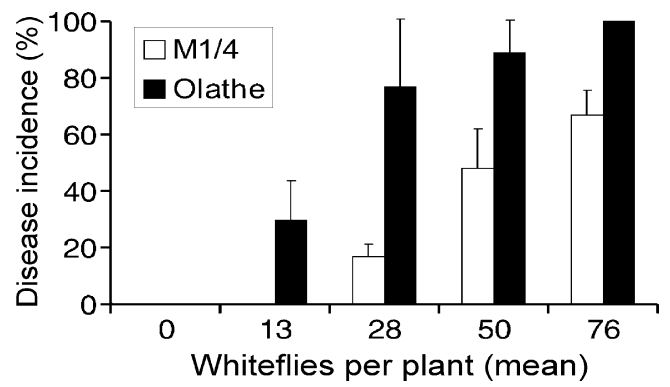

Fig. 6. Disease incidence in transgenic (M1/4) and control (Olathe) plants inoculated with BGMV using whiteflies. Eight-day-old seedlings were exposed to different numbers of viruliferous whiteflies for $72 \mathrm{~h}$. The final number of whiteflies per plant was counted at the end of the inoculation access period. Disease evaluation was done on a visual basis by recording the first date of vein clearing. The experiment was repeated thrice $(n=25)$. Bars represent standard deviations.

\section{Discussion}

There is little natural resistance to BGMV in the Phaseolus spp. as well as in many other host-geminivirus interactions. As a consequence, several researchers have concentrated on efforts to explore strategies of genetically engineered resistance. In this work, efforts were concentrated in the rep gene, mostly due to its being the only geminiviral gene essential for DNA replication [12].

From the total of 17 putative transgenic lines tested, only one line showed resistance to the BGMV. The expression of a transgene located in active chromatin or heterochromatin is highly variable, even among lines independently transformed with the same construct. Many factors may be responsible for variable transgene expression, including the tendency for exogenous DNA to undergo rearrangement prior to integration, effects related to the transgene copy number and integration position, and effects of DNA hypermethylation [22,23].

Out of six plants from the first generation of the line M1/4, tested for resistance to the BGMV, all of them were resistant to glufosinate ammonium, but only four plants were resistant to BGMV. Although the plants were inoculated with the same number of viruliferous whiteflies, it is not possible to control insect feeding. Consequently, there is a possibility of a differential inoculation and distinct response with respect to virus resistance. Indeed, it was further observed to be a dosagedependent virus resistance.

The Southern blot analysis revealed that all generations of the line M1/4 analyzed showed the same pattern, indicating that the copies were integrated at the same locus and that the structure was maintained stable during the eight generations studied. In the first generation, PCR analyses in combination with glufosinate ammonium tolerance assay showed that there was no independent segregation between the bar gene and rep gene cassette. However, in the second generation $\left(T_{2}\right)$, there was no correlation between the numbers of plants showing tolerance to glufosinate ammonium and presenting the rep gene cassette, suggesting that both transgene cassettes were integrated in different loci. The discrepancy between Southern blot analysis and transgenes segregation in the second and third 
generations could be explained by a chimerism in the primary transformant $\left(\mathrm{T}_{0}\right)$. The $\mathrm{T}_{0}$ plant could have distinct transgene integration structures in different parts of the plant.

RT-PCR analysis revealed that both bar and rep gene transcripts were present in transgenic leaves. The rep gene was cloned under control of the doubled 35S promoter from the CaMV plus an AMV enhancer sequence, while the bar gene is under control of a single $35 \mathrm{~S}$ CaMV promoter. Consequently, it was expected to detect higher levels of transcription of the rep gene cassette [15]. However, the amplified fragment from the rep gene was fainter. Both transgenes could be differentially transcribed due to several factors, such as number, position, and functionality of the copies integrated into the genome. In addition, PCR conditions, template DNA, primers, and the size of the amplified fragment may account for a limited amplification.

It was possible to use an antibody raised against the REP protein of a related, but not identical, geminivirus (BGYMV) to detect the expressed mutated REP protein in the transgenic plants. This indicates that the protein produced in the plants may have the correct conformation. As the rep gene is under control of the double CaMV $35 \mathrm{~S}$ promoter, its expression was expected to result in high levels of protein in leaves, stem, and flowers [15]. Nevertheless, the protein could not be detected in seeds. Similar results have been observed in our previous work [21]. It has been observed that the CaMV 35S promoter is inadequate to promote protein accumulation in dry seeds of common beans and other leguminous plants when an amino terminal signal peptide is not added to address the protein to the endoplasmic reticulum $[21,24]$.

There is evidence that a functional protein is necessary to achieve disease resistance [25-27]. However, in some other cases, the use of defective rather than a functional replicase seems to be responsible for the resistance [28,29]. In addition, replicase-mediated protection can be mediated by RNA [30]. RNA-mediated resistance can be achieved by post-transcriptional gene silencing mechanism (co-suppression) [31,32]. The results from the REP protein expression along with those from inoculation of intact plants show that trans-dominant inhibition of BGMV may be mediated by the REP protein in its nonfunctional (mutated) version. The function for the trap and ren genes in the construct were not evaluated in this work, but Hanson and Maxwell [4] suggested, based on protoplast work that they contribute to trans-dominance. In our previous experiments, tobacco protoplasts transformed with the vector pT-M1 were unable to support replication of the B component of BGMV, showing trans-dominance effect over the A component of BGMV, in levels of up to $100 \%$ (J.C. Faria, D.P. Maxwell, unpublished). The resistance level would probably be correlated with the amount of REP protein, and it could be overcome by the wild-type REP protein introduced when a high number of viruliferous whiteflies were present. As common beans are not the most preferred host for whiteflies, the level of resistance reported here may be sufficient to give field control of golden mosaic.

In the present work, the resistance shown by the M1/4 transgenic line seems to be mediated by transgene transcription and translation. However, studies were not carried out to determine if post-transcriptional silencing of the viral genes could also be involved. Transgenic cassava plants were produced containing the wild-type and modified $A C l$ gene from the African cassava mosaic virus. $A C 1$ transcripts were barely detectable in two transgenic lines. However, Western blot assays demonstrated that the protein was present indicating that resistance imparted by the $A C 1$ transgene could be due to protein-based or RNA-based mechanisms, or a combination of both [32].

Our results complement and expand those studies examining the trans-expressed modified rep genes of tomato and cassava geminiviruses for its ability to interfere with the cognate geminivirus replication in Nicotiana benthamiana plants [6,33]. The examination of the transdominance strategy for disease resistance in the virus natural host rather than in Nicotiana sp. showed that the type of resistance observed can be very valuable. Field disease epidemiology data are not complete at this time but the results from greenhouse experiments indicate a significant delay in the onset of symptoms, which would be rather important for the growers, and could lead to important reduction in yield losses. A field experiment to verify this hypothesis was conducted with very promising results, and need replication across years or sites. The results will be published elsewhere.

The research group is currently transferring the transgene to four commercially grown elite cultivars of common beans, using the classical breeding methodology of crossing and backcrossing. No epigenetic effects, which could be due the transformation event, was observed in the progeny, and detailed biosafety studies are under way. Finally, the conservation of NTP binding motifs across all geminivirus rep genes may indicate the usefulness of this strategy to other geminivirushost systems.

\section{Acknowledgments}

We would like to thank Dr. Linda Hanley-Bowdoin (Department of Biochemistry, University of North Carolina, USA) for providing the antibody against the REP protein from BGYMV, and Elsa Nogueira and Warley Almeida for technical assistance.

\section{References}

[1] F.J. Morales, P.K. Anderson, The emergence and dissemination of whitefly-transmitted geminiviruses in Latin America, Arch. Virol. 146 (2001) 415-441.

[2] R.L. Gilbertson, J.C. Faria, P. Ahlquist, D.P. Maxwell, Genetic diversity in geminiviruses causing bean golden mosaic disease: the nucleotide sequence of the infectious cloned DNA components of a Brazilian isolate of bean golden mosaic geminivirus, Phytopathology 83 (1993) 709-715.

[3] J.C. Faria, R.L. Gilbertson, S.F. Hanson, F.J. Morales, P. Ahlquist, A.O. Loniello, D.P. Maxwell, Bean golden mosaic geminivirus type II isolates from the Dominican Republic and Guatemala: nucleotide sequence, infectious pseudorecombinants, and phylogenetic relationships, Phytopathology 84 (1994) 321-329.

[4] S.F. Hanson, D.P. Maxwell, trans-Dominant inhibition of geminiviral DNA replication by bean golden mosaic geminivirus rep gene mutants, Phytopathology 89 (1999) 480-486. 
[5] A.G. Day, E.R. Bejarano, K.W. Buck, M. Burrell, C.P. Lichtenstein, Expression of an antisense viral gene in transgenic tobacco confers resistance to the DNA virus tomato golden mosaic virus, Proc. Natl. Acad. Sci. U.S.A. 88 (1991) 6721-6725.

[6] M. Bendahmane, B. Gronenborn, Engineering resistance against tomato yellow leaf curl virus (TYLCV) using antisense RNA, Plant Mol. Biol. 33 (1997) 351-357.

[7] E. Noris, G.P. Accotto, R. Tavazza, A. Brunetti, S. Crespi, M. Tavazza, Resistance to tomato yellow leaf curl geminivirus in Nicotiana benthamiana plants transformed with a truncated viral $C 1$ gene, Virology 224 (1996) 130-138.

[8] F.J.L. Aragão, S.G. Ribeiro, L.M.G. Barros, A.C.M. Brasileiro, D.P. Maxwell, E.L. Rech, J.C. Faria, Transgenic beans (Phaseolus vulgaris L.) engineered to express viral antisense RNAs showed delayed and attenuated symptoms to bean golden mosaic geminivirus, Mol. Breed. 4 (1998) 491-499.

[9] A. Sangaré, D. Deng, C.M. Fauquet, R.N. Beachy, Resistance to African cassava mosaic virus conferred by a mutant of the putative NTP-binding domain of the Rep gene (AC1) in Nicotiana benthamiana, Mol. Biol. Rep. 5 (1999) 95-102.

[10] Y. Yang, T.A. Sherwood, C.P. Patte, E. Hiebert, J.E. Polston, Use of tomato leaf curl virus (TYLCV) rep gene sequences to engineer TYLCV resistance in tomato, Phytopathology 94 (2004) 490-496.

[11] E.P.B. Fontes, H.J. Gladfelter, R.L. Schaffer, I.T.D. Petty, L. HanleyBowdoin, Geminivirus replication origins have a modular organization, Plant Cell 6 (1994) 405-416.

[12] G. Castillo, L.J. Kong, L. Hanley-Bowdoin, E.R. Bejarano, Interaction between a geminivirus replication protein and the plant sumoylation system, J. Virol. 78 (2004) 2758-2769.

[13] S.F. Hanson, R.A. Hoogstraten, P. Ahlquist, R.L. Gilbertson, D.R. Russell, D.P. Maxwell, Mutational analysis of a putative NTP-binding domain in the replication-associated protein (AC1) of bean golden mosaic geminivirus, Virology 211 (1995) 1-9.

[14] R.L. Gilbertson, J.C. Faria, S.F. Hanson, F.J. Morales, P. Ahlquist, D.P. Maxwell, D.R. Russell, Cloning of the complete DNA genomes of four bean-infecting geminiviruses and determining their infectivity by electric discharge particle acceleration, Phytopathology 81 (1991) 980-985.

[15] R.S. Datla, J.K. Hammerlindl, L.E. Pelcher, W.L. Crosby, G. Selvaraj, A bifunctional fusion between beta-glucorinidase and neomycin phophotranferase: a broad-spectrum marker enzyme for plants, Gene 101 (1991) 239-246.

[16] T.A. Kunkel, J.D. Roberts, R.A. Zakour, Rapid and efficient site-specific mutagenesis without phenotypic selection, in: R. Wu (Ed.), Recombinant DNA Methodology, Academic Press, 1989, pp. 587-601.

[17] F.J.L. Aragão, G.R. Vianna, M.M.C. Albino, E.L. Rech, Transgenic dry bean tolerant to the herbicide glufosinate ammonium, Crop Sci. 42 (2002) 1298-1302.

[18] F.J.L. Aragão, L.M.G. Barros, A.C.M. Brasileiro, S.G. Ribeiro, F.D. Smith, J.C. Sanford, J.C. Faria, E.L. Rech, Inheritance of foreign genes in transgenic bean Phaseolus vulgaris L.) co-transformed via particle bombardment, Theor. Appl. Gen. 93 (1996) 142-150.
[19] K. Edwards, C. Johnstone, C. Thompson, A simple and rapid method for the preparation of plant genomic DNA for PCR analysis, Nucl. Acids Res. 19 (1991) 1349

[20] J. Sambrook, D.W. Russell, Molecular Cloning: A Laboratory Manual, third ed., Cold Spring Harbor Laboratory Press, Cold Spring Harbor, New York, 2001.

[21] F.J.L. Aragão, L.M.G. Barros, M.V. Sousa, M.F. Grossi-de-Sá, E.R.P. Almeida, E.S. Gander, E.L. Rech, Expression of a methionine-rich storage albumin from Brazil nut (Bertholletia excelsa H.B.K., Lecythidaceae) in transgenic bean plants (Phaseolus vulgaris L., Fabaceae), Gen. Mol. Biol. 22 (1999) 445-449.

[22] R. Abranches, A.P. Santos, E. Wegel, S. Williams, A. Castilho, P. Christou, P. Shaw, E. Stoger, Widely separated multiple transgene integration sites in wheat chromosomes are brought together at interphase, Plant J. 24 (2000) 713-723.

[23] P. Meyer, Stabilities and instabilities in transgene expression, in: K. Lindsey (Ed.), Transgenic Plant Research, Harwood Academic, 1998, pp. 263-275.

[24] I. Saalbach, D. Waddell, O. Schieder, K. Muntz, Stable expression of the sulphur-rich 2S-albumin gene in transgenic Vicia narbonensis increases the methionine content of the seeds, J. Plant Physiol. 145 (1995) 674 681.

[25] J.P. Carr, L.E. Marsh, G.P. Lomonossoff, M.E. Sekiya, M. Zaitlin, Resistance to tobacco mosaic virus induced by the 54-kDa gene sequence requires expression of the 54-kDa protein, Mol. Plant-Microbe Interact. 5 (1992) 97-104.

[26] A.S. MacFarlane, J.W. Davies, Plants transformed with a region of the 201-kilodalton replicase gene from pea early browning virus RNA 1 are resistant to virus infection, Proc. Natl. Acad. Sci. U.S.A. 89 (1992) 5829 5833.

[27] F.T. Brederode, P.E.M. Taschner, E. Posthumus, J.F. Bol, Replicasemediated resistance to alfafa mosaic virus, Virology 207 (1995) 467474.

[28] J.M. Anderson, P. Palukaitis, M. Zaitlin, A defective replicase gene induces resistance to cucumber mosaic virus in transgenic tobacco plants, Proc. Natl. Acad. Sci. U.S.A. 89 (1992) 8759-8763.

[29] D.C. Baulcombe, Replicase-mediated resistance: a novel type of virus resistance in transgenic plants? Trends Microbiol. 2 (1994) 60-63.

[30] R.C. Vazquez, S. Asurmendi, H.E. Hopp, Transgenic resistance in potato plants expressing potato leaf roll virus (PLRV) replicase gene sequences is RNA-mediated and suggests the involvement of post-transcriptional gene silencing, Arch. Virol. 146 (2001) 1337-1353.

[31] J.J. English, E. Mueller, D.C. Baulcombe, Suppression of virus accumulation in transgenic plants exhibiting silencing of nuclear genes, Plant Cell 8 (1996) 179-188.

[32] P. Chellappan, M.V. Masona, R. Vanitharani, N.J. Taylor, C.M. Fauquet, Broad spectrum resistance to ssDNA viruses associated with transgeneinduced gene silencing in cassava, Plant Mol. Biol. 56 (2004) 601-611.

[33] Y. Hong, J. Stanley, Virus resistance in Nicotiana benthamiana conferred by African cassava mosaic virus replication-associated protein (AC1) transgene, Mol. Plant-Microbe Interact. 9 (1996) 219-225. 